\title{
A NEW DENTURE LABELING SYSTEM AS AN ANTE-MORTEM RECORD FOR FORENSIC IDENTIFICATION
}

\author{
$B \mathcal{Y}$ \\ Mona Sayed El-Gohary, Khaled Mahmoud Saad, \\ Mohamed Maamoun El-Sheikh* and Tamer Mohamed Nasr* \\ Departments of Forensic Medicine and Clinical Toxicology, Faculty of Medicine, \\ and Prosthodontic, Faculty of Dentistry*, Tanta University
}

\begin{abstract}
Dental prostheses labeled with the patient's name and further unique identifiers such as gender, phone number, address, job and national identity number may play an important role in forensic casework's. This article describes a new technique for placing identification tags within the acrylic or metallic removable dentures in a simple and cheap way that satisfy all the forensic requirement for a suitable denture marker. So, helping in denture identification in forensic dentistry.
\end{abstract}

Key words: Forensic dentistry, denture labeling, denture identification tags.

\section{INTRODUCTION}

In mass disasters, identification of unknown cadavers is important not only from a humanitarian point of view but also for legal reasons and in connection with insurance. Various identification techniques are available today, such as finger printing, DNA profiling and the comparison of dental structures. Not all methods of identification are equally useful in practice and the ultimate identification is often made possible only by a combination of several techniques (Delattre and Stimson, 1999).
In major disasters, a special Disaster Identification Team is activated, consisting mainly of police officers supplemented by external experts including forensic odontologists. Identification may be applied to one victim or multiple victims (Bowers and Bell, 1995).

Therefore, dental prostheses labeled with at least the patient's name and further unique identifiers such as gender, phone number, address, job and national identity number may play an important role in forensic casework's (Stenberg and Borrman, 1998). 
Denture labeling systems can be broadly separated into inclusion systems, marking systems. Most of them are either time consuming, esthetically unpleasant, using equipments not readily available in most of dental laboratories particularly in developing countries and if the denture needs relining, the denture label becomes invisible (Richmond and Pretty, 2006). However, very little is known about the resilience of such systems to conditions experienced in the majority of post- and perimortem assault (Richmond and Pretty, 2009).

Therefore, the purpose of this study is to introduce a new, easy denture labeling system that is durable, cheap, secure and applicable in forensic casework's.

\section{MATERIAL, METHODS AND RESULTS}

In this study, the lead foil paper found in the periapical or occlusal $x$ ray film, (about $1 \mathrm{~mm}$ in thickness) was used.

Procedure for denture labeling was done in seven steps as follows:

1- Type the patient's data such as name, gender, national identity number, phone number, country, and job on the foil paper with any manual ribbon typewriter using a character of 8- point font size after taking a written consent.
2- Cut the foil paper into small pieces according to denture size, each one represents a patient label. (Fig-1).

3- After waxing the denture up, and during flasking and packing, put a small amount of the heat cure acrylic resin in the posterior-lateral area of the palate (fig-2), then place a wet cellophane paper and perform the trial closure.

4- Re-open the flask, remove any flashes with a sharp knife, put the identification label, it is best placed in the maxillary posterior-lateral area of the palate (figure$3)$, the posterior buccal flange and in the mandibular lingual flange.

5- Pack the rest of the acrylic resin, then close the flask, cure the denture, deflask, trim and polish the denture to complete the procedures.

6- Alternatively, the label can be incorporated after the denture is processed by cutting a depression of approximately $1 \mathrm{~mm}$ deep, slightly wider than the size of the label. The label can then be covered with a thin layer of light cured acrylic resin of the same color of the heat cure acrylic resin.

7- A radiographic periapical film is taken to the denture; (using an x-ray machine with 10 seconds exposure time), the patient's details will appear clearly (figure 4). 


\section{DISCUSSION}

Identification is an essential requirement of any medicolegal investigation because a mistaken identity may pose a problem in delivering justice. Various parameters like facial features, scars, tattoos, deformities, peculiarities and personal belongings can assist in the identity of a person. When all these parameters fail to identify a body as in case of $100 \%$ burns or putrefaction or bodies recovered from water or in case of severely traumatized patients in particular the mass causalities normally associated with aviation disasters, dental identification continues to be crucial, as the teeth and the jaw, which appear to withstand a great deal of trauma than the rest of the body, can solve this difficulty (Andersen et al., 1995).

The frequency of edentulousness has not changed in the present. Edentulous persons represent nearly $2 \%$ of population (Madléna et al., 2008). The oral status of population varies in different countries, and the wearing of complete denture will be a fact for the future. Hence there is a need to address the issue of denture marking for social and legal problems (Borrman et al., 1995).

The lead paper label used in this study for denture marking appears to satisfy all requirements recommended for denture markers. It is biologically inert (when in- corporated into the denture), durable, not expensive, easy to inscribe, possible to retrieve after an accident, and survive elevated temperature for a reasonable time under normal circumstances, and doesn't affect the strength of the denture due to its malleability (Borrman et al., 1999).

Over the years, several methods of denture labeling have been reported in the literature, these techniques include surface marking, inclusion techniques using metal or nonmetal materials, micro labels and microchips. These techniques are either time consuming, esthetically unpleasant, using equipments not readily available in most of dental laboratories and if the denture needs relining, the denture label becomes invisible (Richmond and Pretty, 2006).

Although, microchips inclusion techniques such as radio-frequency identification (RFID)-tags, florescence markers and other advanced inclusion techniques within dental prostheses have been suggested as means of effectively labeling dentures and permitting rapid and reliable identification of the wearer. However, these techniques are very expensive, as they exceed far the cost of the acrylic denture. In addition they need sophisticated equipments for fabricating microchips and its reading that don't suit a developing country. Moreover, microchips are considered weak point in the denture structure as it 
should be put after denture processing and should be put in an area subjected to be relined (Millet and Jeannin, 2004).

Lead papers used in this study are easily available, not expensive and their incorporation into the denture as well as its reading don't need sophisticated techniques. In addition, lead paper can withstand heat and put in an area in the denture not subjected to relining that could be considered as advantages over microchips inclusion labels.

Although stainless steel band can withstand more thermal insult yet it isn't as malleable as lead. It also represents a weak point in the denture as during denture processing it is difficult to pack stainless steel as it can separate the denture and weaken it.
Since there is no international consensus regarding the issue of denture marking it is important to address it and suggest newer methods for its identification (Borrman et al., 1995). A survey from the Nordic countries has shown that if denture marking was in general use, the establishment of identity by forensic odontology in cases of fire would increase by about $10 \%$. Increased international collaboration is needed to solve the issue of denture marking for clinical and forensic purposes (Borrman et al., 1999).

The technique proposed in this article is easy, cosmetically appealing, cost effective and able to satisfy all the forensic requirement for a suitable denture marker. Routine marking of all dentures by this method is advocated. 


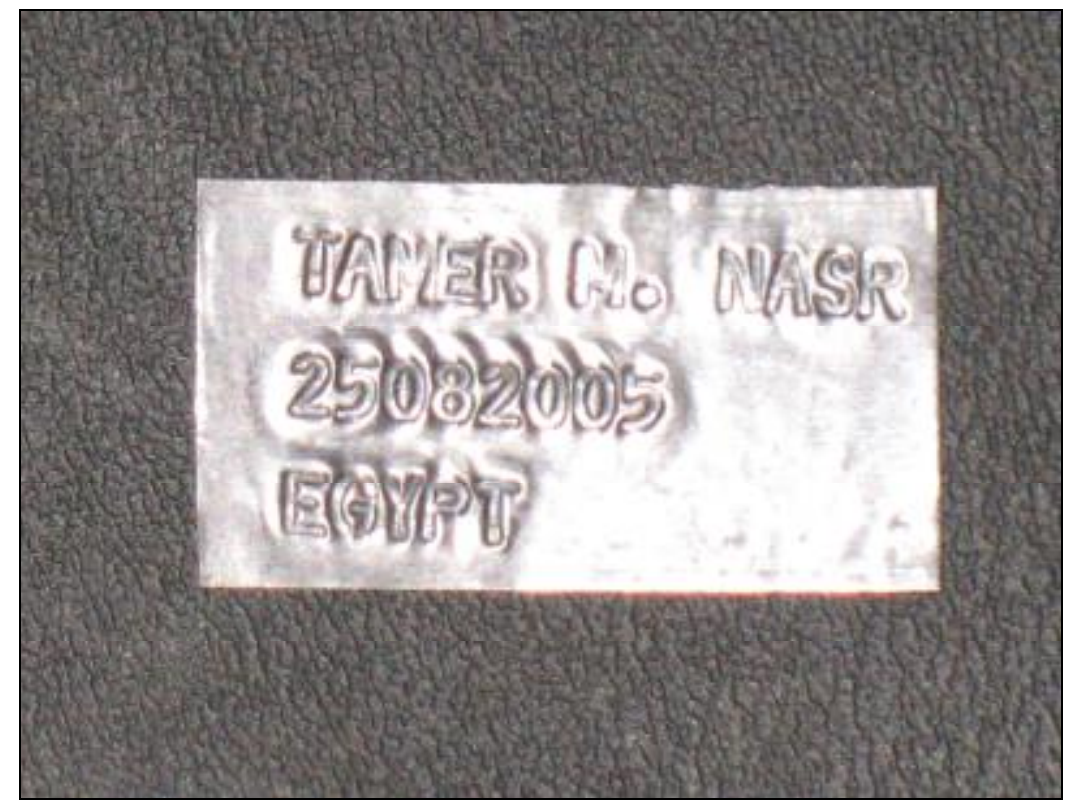

Fig. (1) : Patient label on foil paper.

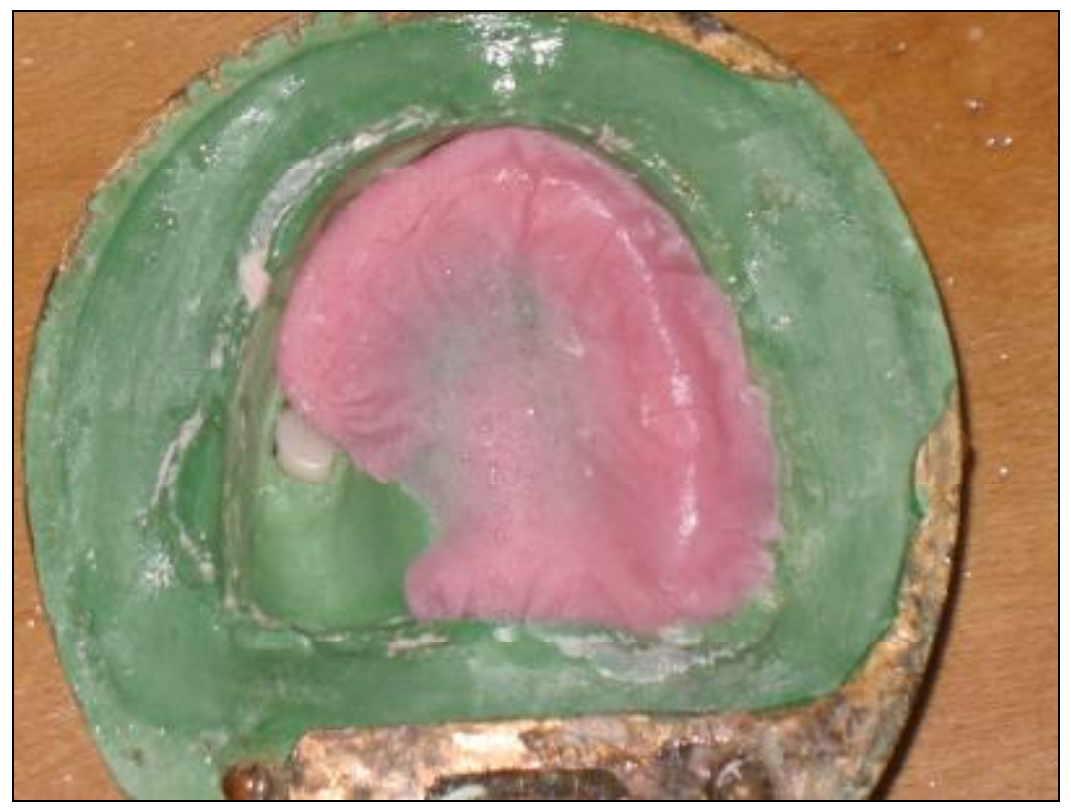

Fig. (2) : Heat cure acrylic resin in the posterior-lateral area of the palate. 


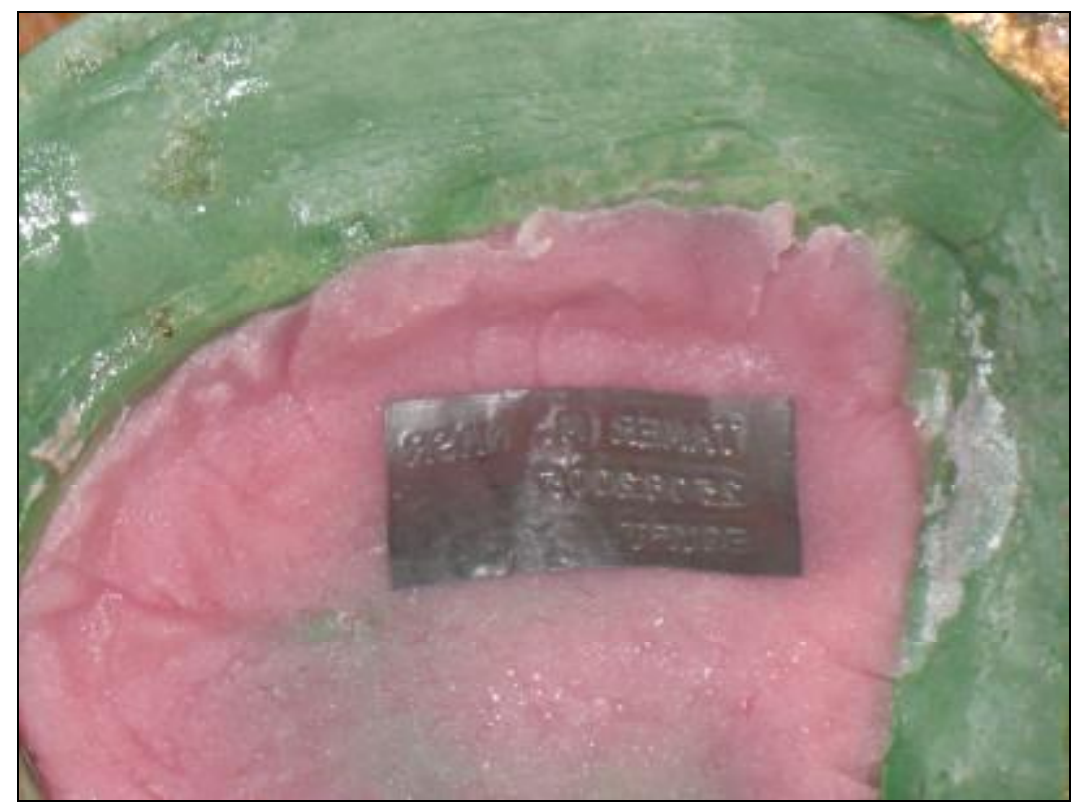

Fig. (3) : Placing the label in the maxillary posterior lateral area of the palate.

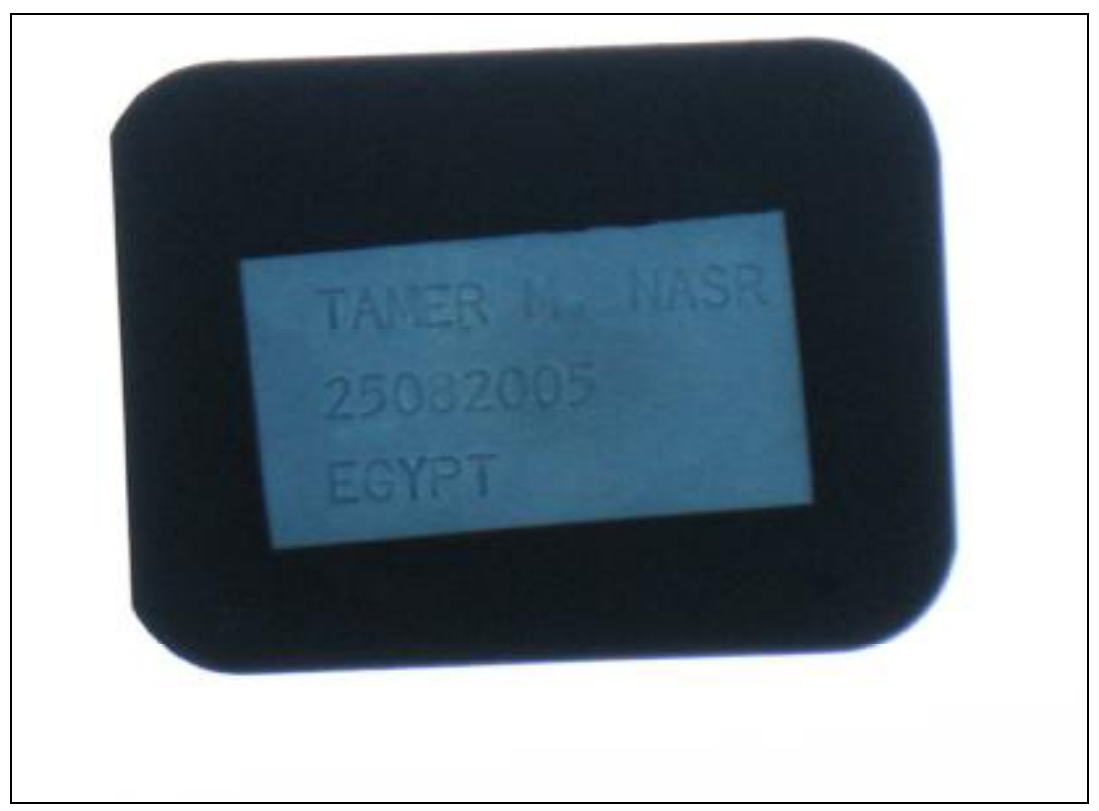

Fig. (4) : A radiographic periapical film to the denture showing clear patient's details. 


\section{REFERENCES}

Andersen, L.; Juhl, M.; Solheim, T. and Borrman H. (1995) : “Odontological identification of fire victims- potentialities and limitations". Int. J. Legal Med.,107:229-234.

Borrman, H.; Thomas, C. J. and Engstrom, E. U. (1995) : “Denture marking. Clinical and technical aspects". J. Forensic Odontostomatol., 13 (1):14-17.

Borrman, H. I.; DiZinno, J. A.; Wasen, J. and Rene, N. (1999) : "On denture marking". J. Forensic Odontostomatol., 17 (1):20-26.

Bowers, C. M. and Bell, G. L. (1995) : Manual of Forensic Odontology. Publication of the American Society of Forensic Odontology (ASFO); P.P. 1-9.

Delattre, V. F. and Stimson, P. G. (1999) : "Self assessment of the forensic value of dental records". J. Forensic Sci., 44:906-909.

Madléna, M.; Hermann, P.; Jáhn, M. and Fejérdy, P. (2008) : “Caries prevalence and tooth loss in Hungarian adult population: results of a national survey". BMC Public Health, 8:364.

Millet, C. and Jeannin, C. (2004) : "Incorporation of microchips to facilitate denture identification by radiofrequency tagging". J. Prosthet. Dent., 92:588-590.

Richmond, R. and Pretty, I. A. (2006) : "Contemporary methods of labeling dental prostheses--a review of the literature". J. Forensic Sci., 51(5):1120-1126.

Richmond, R. and Pretty, I. A. (2009) : "A range of postmortem assault experiments conducted on a variety of denture labels used for the purpose of identification of edentulous individuals". J. Forensic Sci.,54(2):411-414.

Stenberg, I. and Borrman, H. I. (1998) : "Dental condition and identification marking of dentures in homes for the elderly in Goteborg, Sweden". J. Forensic Odontostomatol.,16(2):35-37. 


\section{طريقة جديدة لتمييز أطقم الأسنان تستخدم كسجل قبل الوفاة

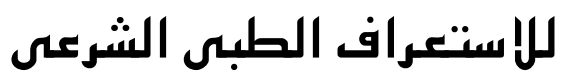

$$
\text { المشتركون فى البحث }
$$

د. خالح هــهود سعد

د. هنس سـيد الجوهـرى

د. تاعـر هــــد نصر

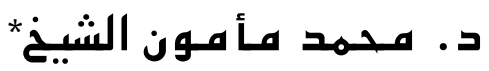

$$
\text { قسم الاستعام الطب الشـرعى والسموم الإكلينيكية - كلية الطب }
$$

تلعب أطقم الأسنان التى تم كتابة إسم وبيانات المريض عليها دوراً هاماً فى مجالات الطب الشرعى، ويتناول هذا البحث طريقة جديدة لوضع

علامات مميزة للمريض على أطقم الأسنان الإكريليك أو المعدنية بطريقة بسيطة وغير مكلفة وتفى باحتياجات الطب الشرعى مماقد يساعد على الاستعراف على الشخص حين تدعو الضرورة لذلك. 